\title{
sciendo
}

\section{Thyroid hormone and thyroid hormone nuclear receptors: History and present state of art}

\author{
Julius BRT ко \\ Institute of Experimental Endocrinology, Biomedical Research Center, Slovak Academy of Sciences, Bratislava, Slovakia \\ E-mail: julius.brtko@savba.sk
}

\begin{abstract}
The present review traces the road leading to discovery of L-thyroxine, thyroid hormone (3,5,3' -triiodo-L-thyronine, $\left.\mathrm{T}_{3}\right)$ and its cognate nuclear receptors. Thyroid hormone is a pleiotropic regulator of growth, differentiation, and tissue homeostasis in higher organisms. The major site of the thyroid hormone action is predominantly a cell nucleus. $T_{3}$ specific binding sites in the cell nuclei have opened a new era in the field of the thyroid hormone receptors (TRs) discovery. $\mathrm{T}_{3}$ actions are mediated by high affinity nuclear TRs, TRalpha and TRbeta, which function as $\mathrm{T}_{3}$-activated transcription factors playing an essential role as transcription-modulating proteins affecting the transcriptional responses in target genes. Discovery and characterization of nuclear retinoid X receptors (RXRs), which form with TRs a heterodimer RXR/TR, positioned RXRs at the epicenter of molecular endocrinology. Transcriptional control via nuclear RXR/TR heterodimer represents a direct action of thyroid hormone. $T_{3}$ plays a crucial role in the development of brain, it exerts significant effects on the cardiovascular system, skeletal muscle contractile function, bone development and growth, both female and male reproductive systems, and skin. It plays an important role in maintaining the hepatic, kidney and intestine homeostasis and in pancreas, it stimulates the beta-cell proliferation and survival. The TRs cross-talk with other signaling pathways intensifies the $\mathrm{T}_{3}$ action at cellular level. The role of thyroid hormone in human cancers, acting via its cognate nuclear receptors, has not been fully elucidated yet. This review is aimed to describe the history of $\mathrm{T}_{3}$ receptors, starting from discovery of $\mathrm{T}_{3}$ binding sites in the cell nuclei to revelation of $\mathrm{T}_{3}$ receptors as $\mathrm{T}_{3}$-inducible transcription factors in relation to $\mathrm{T}_{3}$ action at cellular level. It also focuses on milestones of investigation, comprising RXR/TR dimerization, cross-talk between $\mathrm{T}_{3}$ receptors, and other regulatory pathways within the cell and mainly on genomic action of $\mathrm{T}_{3}$. This review also focuses on novel directions of investigation on relationships between $T_{3}$ receptors and cancer. Based on the update of available literature and the author's experimental experience, it is devoted to clinicians and medical students.
\end{abstract}

Key words: thyroid hormone, nuclear thyroid hormone receptor, gene expression, thyroid hormone-inducible transcription factor, retinoid $\mathrm{X}$ receptor, molecular mechanism of action

The first indirect references regarding the thyroid gland, which are predominantly linked with its diseases, have appeared in the texts of Egyptian, Chinese and later also of ancient Greek medicine dating back to $2700 \mathrm{BC}$. Due to a goiter widespread prevalence in population, it has always been a disease of immense interest (Niazi et al. 2011). In the $6^{\text {th }}$ century, Aetius made the reference to the surgical treatment of goiter, which was considered to be a hernia of the larynx (Marketos et al. 1990). In 1656, an anatomist Thomas Wharton described the anatomical structure of the thyroid gland along with the other glands of the body. Moreover, he demonstrated that the primary function of thyroid gland

Corresponding author: Julius Brtko, PhD., DSc., Biomedical Research Center, Institute of Experimental Endocrinology, Slovak Academy of Sciences, Dubravska cesta 9, Bratislava, Slovakia; phone: +421-2-3229 5277; e-mail: julius.brtko@savba.sk. 
is secretion. In 1907, David Marine proved that an element iodine is necessary for thyroid function (Niazi et al. 2011).

In 1914, Edward Calvin Kendall underwent hydrolysis of the enormous amount of the bovine thyroid glands and he succeeded with the first isolation of crystalline thyroxine (Kendall 1915). Later on, thyroxine was prepared synthetically by condensation of two molecules of diiodotyrosine, which led to the description of the exact structure of thyroxine. (Harington and Barger 1927). A breakthrough in the thyroidology came with the discovery of Jack Gross and Rosalind Pitt-Rivers (1952) postulating that 3,5,3'-triiodo-L-thyronine $\left(\mathrm{T}_{3}\right)$ is the "true" peripheral thyroid hormone, while the L-thyroxine $\left(\mathrm{T}_{4}\right)$ is its precursor.

In the second half of the previous century, the radioligand binding assays, using the radioisotope iodine $\left({ }^{125} \mathrm{I}\right)$ with high specific activity, opened at least three decades of thoughtful investigation on thyroid hormone binding sites in the cell organelles in relation to mechanism of thyroid hormone action. Tabachnick et al. (1954) have demonstrated distribution of labelled thyroxine in rat liver homogenates and demonstrated only non-specific binding. Later, the binding of both radiolabeled compounds $\left(\mathrm{T}_{4}\right.$ and $\mathrm{T}_{3}$ ) to mitochondria and microsomes isolated from rat liver and skeletal muscle (Tata et al. 1962), and also to soluble proteins of rat liver (Spaulding and Davis 1971) has been demonstrated.

\section{From $T_{3}$ binding sites in nucleus to $T_{3}$ receptors}

Even in 1967, Tata and his co-workers were the first who contemplated that thyroid hormone might be capable to initiate its action by stimulating gene transcription. Next year will be half a century since Oppenheimer and his colleagues (1972) brought the first strong evidence that nuclei from rat liver and kidney possess a set of receptor sites, which exhibit specificity for $T_{3}$. These receptors exert high affinity and limited capacity to $\mathrm{T}_{3}$ binding in nuclei. Specific binding of $\mathrm{T}_{4}$ to nuclei was also confirmed, but it represented only the one-tenth of that exhibited by $\mathrm{T}_{3}$ (Surks et al. 1973, 1975; Koerner et al. 1975). Consequently, a correlation between the affinity of the nuclear $\mathrm{T}_{3}$ binding sites and the biological potency of thyroid hormone has been confirmed, as well (Koerner et al. 1975; Oppenheimer et al. 1976). The presence of specific nuclear $\mathrm{T}_{3}$ binding sites - nuclear thyroid hormone receptors (TRs) in various tissues has been demonstrated by many independent groups of investigators (Oppenheimer et al. 1974; Samuels et al. 1974; DeGroot and Torresani 1975; Eberhardt et al. 1978) and the support for $T_{3}$ mitochondrial receptors has been rather less forthcoming (Sterling et al. 1977; Naidoo et al. 1978). Nuclear TRs were found to be acidic non-histone chromatin proteins, easily extractable in high ionic strength solutions, what enabled investigators to employ further analyses to study their biological, biochemical, and physicochemical properties (Samuels et al. 1974; Surks et al. 1975; Torresani and DeGroot 1975; Barsano et al. 1990). The presence of TRs was also confirmed in cultured rat tumor pituitary $\mathrm{GH}_{1}$ cells that were found to respond to $\mathrm{T}_{3}$ with augmented growth hormone (GH) secretion (Samuels and Tsai 1973; Samuels et al. 1979). Rat liver nuclear TR was found to be rather unstable protein, which loses its $\mathrm{T}_{3}$ binding activity at $0^{\circ} \mathrm{C}$ with a half-life of approximately 14 days or with a half-life of approximately 62 minutes at $36^{\circ} \mathrm{C}$. The effect of glycerol on protection against loss of nuclear TR binding activity was clearly shown by heat-inactivation study and other in vitro analyses (Brtko et al. 1987, 1992a; Ichikawa et al. 1989). The TR was demonstrated to be unstable at a $\mathrm{pH}$ below 6.0 or above 10.0. Using a set of commercially available resins for purification of proteins (hydroxylapatite, Sephadex G-150, DNA-cellulose, DEAE-Sephadex A-150, heparin-sepharose), the protein fraction containing nuclear TR proteins has been purified to its relative value of the maximal binding capacity of $1220 \mathrm{pmol} / \mathrm{mg}$ protein with a final yield of $14.6 \mu \mathrm{g}$ per $4 \mathrm{~kg}$ of rat liver (Ichikawa et al. 1989).

Protease inhibitors and substrates were found to inhibit steroid molecules binding to their cognate receptors (Baker et al. 1978; Hubbard and Kalimi 1985; Puca et al. 1986). These findings have been extended for TRs, showing that various protease inhibitors and protease substrates inhibit $\mathrm{T}_{3}$ binding to nuclear TRs (Brtko et al. 1993).

The presence of saturable and high affinity $\mathrm{T}_{3}$ binding sites was also demonstrated in nuclei of L1210 murine leukemia cells. Scatchard analysis revealed one class of nuclear receptors for $T_{3}$ with the $\mathrm{K}_{\mathrm{a}}=2.187 \times 10^{9} \mathrm{l} / \mathrm{mol}$ and the maximum binding capacity $\left(\mathrm{B}_{\max }\right)$ of $3.96 \mathrm{fmol} / 10^{6}$ cells, what represents $2385 \mathrm{~T}_{3}$ receptor sites per nucleus (Brtko et al. 1992b). In L1210 murine leukemia cells, processes linked to $\mathrm{T}_{3}$ receptor promotion in cell nuclei were effective within the late $G_{1}$ and $S$ phases of the cell cycle, and thus the increase in $\mathrm{T}_{3}$ receptor concentration in the nuclei was positively correlated with the number of cells in the S compartment of the cell cycle (Filipcik et al. 1992). The number of nuclear receptors for $\mathrm{T}_{3}$ in the liver may be reduced by starvation, 
glucagon treatment or partial hepatectomy (DeGroot et al. 1977a; Dillmann et al. 1978; Brtko and Knopp 1988). The most important property of the $\mathrm{T}_{3}$-nuclear receptor complex is its ability to stimulate transcription of target genes (DeGroot et al. 1977b; Glass and Holloway 1990; Brtko et al. 1994).

The data on the thyroid hormone binding to nuclei or nuclear proteins achieved during the second half of the previous century clearly demonstrate that the cell nucleus is the principal site for the initiation of thyroid hormone action (Oppenheimer 1999).

\section{Nuclear $T_{3}$ receptors $-T_{3}$-inducible transcrip- tion factors}

A remarkable breakthrough in the field of nuclear TRs investigation came in the year 1986, with the discovery of two research groups showing that the c-erbA proto-oncogene, a cellular counterpart of the viral v-erbA oncogene, encodes a high affinity receptor for thyroid hormone. The laboratory of Björn Vennström succeeded in the cloning of the alpha form of thyroid hormone receptor (TRalpha), while the beta form of thyroid hormone (TRbeta) was accomplished in the laboratory of Ronald Evans (Weinberger et al. 1986; Sap et al 1986; Thompson et al. 1987). Based on the above-mentioned reports, this breakthrough has triggered years of intense investigations on nuclear TRs, which significantly contributed to the identification of TRalpha1, TRbetal and TRbeta2 receptors as thyroid hormone dependent transcription factors. In mammals, two distinct but closely related genes encode TRs. The human alpha- $\mathrm{T}_{3}$ receptor gene has been localized to chromosome 17 (Thompson et al. 1987; Benbrook and Pfahl 1987; Koenig et al. 1988) and the human beta- $\mathrm{T}_{3}$ receptor gene to chromosome 3 , and it was reported to be tightly linked to the autosomal dominant syndrome of thyroid hormone resistance (Usala et al. 1988a; Glass and Holloway 1990).

TRalpha is ubiquitously expressed in vertebrates, however, TRbeta expression patterns were demonstrated predominantly in the liver, pituitary, inner ear, retina, and several brain areas (Flamant et al. 2006). The reports of Vennström's and Evans' groups markedly contributed to the discovery of "superfamily" of 48 genes present in the human genome, which comprises regulatory genes responsible for the coding nuclear receptors for glucocorticoids, mineralocorticoids, androgen, estrogen, progesterone, dihydroxyvitamin $\mathrm{D}_{3}$, all-trans and 9-cis retinoic acids and many other "orphan" nuclear receptors, for which the ligand still remains unknown (Giguere et al. 1987; Evans 1988; Giguere et al. 1988; Green and Chambon 1988; Glass and Holloway 1990; Laudet et al. 1992).

All known nuclear receptors consist of a variable $\mathrm{NH}_{2}$-terminal domain $(\mathrm{A} / \mathrm{B})$, the domain $\mathrm{C}$, which is a conserved DNA binding region, a linker region $\mathrm{D}$, possessing a role as a hinge of the nuclear receptor molecule, and a conserved $\mathrm{E}$ domain that contains the ligand binding domain. Several nuclear receptors contain also a terminal $\mathrm{F}$ region containing a carboxyl group, the function of it still remains unknown (Evans 1988; Aranda and Pascual 2001). The domain C contains two "zinc fingers", which contain DNA recognition motifs forming with amino acids at the base of the first zinc finger the specific region known as „P-box“. The amino acid residues of the second zinc finger form the structure termed as " $\mathrm{D}$ box", which is involved in the nuclear receptor dimerization (Dahlman-Wright et al. 1993; Nelson et al. 1994; Zechel et al. 1994). The "P-box" is critical for identifying the primary nucleotide sequence of the half sites, while the "D-box" is important for the determination of the half-site spacing (Umesono and Evans 1989). Moreover, nuclear receptors contain two regions required for transcriptional activation, the hypervariable region located at the amino group end of the receptor molecule, which contains an autonomous transcriptional activation function, known as AF-1 that contributes to constitutive ligand independent activation by the nuclear receptor molecule. The second transcriptional activation domain, termed as AF-2, is located in the carboxyl group containing terminus of the nuclear receptor ligand binding domain. The transactivation domain AF-2 is strictly ligand dependent and conserved among members of the nuclear receptor superfamily (Barettino et al. 1994; Aranda and Pascual 2001).

TRs, similarly like other nuclear receptors, contain a variable $\mathrm{N}$-terminal domain, a DNA binding domain followed by a hinge region, and a C-terminal ligand binding, dimerization, and transactivation domain. The TRalpha gene is transcribed as TRalpha1 and TRalpha 2 mRNAs, which differ by alternative splicing of 39 exons, resulting in distinct $\mathrm{C}$ terminal domains. TRalphal binds $\mathrm{T}_{3}$ and DNA and is a functional $\mathrm{T}_{3}$ receptor, whereas TRalpha2 fails to bind $\mathrm{T}_{3}$ and acts as a weak antagonist (Harvey and Williams 2002). The TRbeta gene is transcribed as TRbeta1 and TRbeta 2 mRNAs, which are generated by separate promoter and alternative splicing in the 5 ' region resulting in distinct beta 1 and beta 2 protein N-termini (Williams 2000; Harvey and Williams 2002). 
In 1990, the first identified nuclear retinoid X receptor (RXR), referred as RXRalpha, was initially described as an orphan receptor (Mangelsdorf et al. 1990). Two years later, three RXR genes (RXRalpha, RXRbeta, RXRgamma) were discovered and subsequently thoroughly characterized. In the same year, it has been demonstrated that retinoid $\mathrm{X}$ receptors (RXRs) interact with several nuclear receptors in signaling pathways mediated by all-trans retinoic acid (RA), thyroid hormone and vitamin $\mathrm{D}_{3}$. In addition, 9-cis retinoic acid (9cRA) was confirmed to be a high affinity ligand for the RXR (Mangelsdorf et al. 1992; Kliewer et al. 1992; Heyman et al. 1992). Discovery and characterization of RXRs positioned them at the epicenter of the "Big Bang" of molecular endocrinology and gave rise to huge wave of novel discoveries, including new physiologic signaling pathways (Evans and Mangelsdorf 2014; Yamada and Kakuta 2014). RXRs perform their role as promiscuous dimerization partners for additional nuclear receptors, which act in a variety of nuclear receptor facilitated pathways (Germain et al. 2006a; Krezel et al. 2019; Brtko and Dvorak 2020). RXR molecules form permissive heterodimers with peroxisome proliferator-activated receptors (PPARs), liver $\mathrm{X}$ receptors (LXRs), farnesoid X receptor (FXR), pregnane $\mathrm{X}$ receptor (PXR) and constitutive androstan receptor (CAR). RXR/TR heterodimers are thought to be non-permissive for RXR, but several studies have suggested that there may be exceptions in specific cellular contexts (Castillo et al. 2004; Mengeling and Furlow 2015; Flamant 2016). Retinoid receptors (RARs) and TRs may form conditional heterodimers, and dihydroxyvitamin $\mathrm{D}_{3}$ receptor (VDR) is at present believed to form nonpermissive heterodimer (Laudet 1997; Sanchez-Martinez et al. 2006; Yamada and Kakuta 2014; Brtko and Dvorak 2020).

Both types of TRs (TRalpha and TRbeta) are functionally active in the form of conditional heterodimer RXR/TR, which bind to thyroid hormone response elements (TREs) (Germain et al. 2006b; Brtko and Dvorak 2011). The TREs have been shown to consist of either the palindrome pair of hexameric (AGGTCA) "half-sites" or direct repeats of this sequence spaced by a "gap" containing preferentially four nucleotides (Glass et al. 1988; Wahlstrom et al. 1992). RXR molecule, as a part of heterodimer in a conditional heterodimer does not respond to rexinoids, nevertheless, RXR agonists are capable to superactivate transcription of target genes by synergizing with the action of $\mathrm{T}_{3}$ bound to TRs. Functional evidences on the role of RXR ligand in the RXR/TR heterodimer have already been demonstrated (Li et al. 2002; Castillo et al. 2004; Brtko and Dvorak 2020). The interaction of the nuclear TRs with specific DNA sequences represents the crucial mechanism by which the transcription of target genes is controlled.

The discovery of coregulators (coactivators and corepressors) of nuclear receptors has greatly enhanced the understanding of TRs function. SMRT (silencing mediator of retinoic acid and thyroid hormone receptor) and $\mathrm{N}-\mathrm{CoR}$ (nuclear receptor corepressor) are two related transcriptional corepressors that contain separable domains capable of interacting with unliganded nuclear receptors and repressing basal transcription. The first reported functional nuclear receptor coactivator, termed the steroid receptor coactivator-1 (SRC-1), is considered to be a general coactivator for all steroid/thyroid subfamily of nuclear receptors and upon a ligand binding to cognate nuclear receptors, is responsible for the enhancement of transactivation of hormonedependent target genes. In the other words, upon binding of the corresponding ligand, the nuclear receptors change their conformation in the ligandbinding domain that enables recruitment of coactivators, which allows the receptor to interact with the basal transcriptional machinery efficiently and to activate transcription of thyroid hormone-dependent genes (Horlein et al. 1995; Glass 1996; Shibata et al. 1997; Li et al. 1997). Among nuclear receptor coactivators also belong the transcriptional intermediary factor 2 (TIF2/GRIP-1/NCoA-2), the cAMPresponse element binding protein (CREB)-binding protein (CBP), the $\mathrm{p} 300 / \mathrm{CBP}$-associated factor ( $\mathrm{p} /$ $\mathrm{CAF}$ ), the vitamin $\mathrm{D}$ receptor-interacting protein/ TR-associated protein (DRIP/TRAP), and the mediator complex subunit $21(\mathrm{MED} / 21)$, known as Srb7 (Nevado et al. 2004; Smith and O'Malley 2004; Rosenfeld et al. 2006; Giammanco et al. 2020).

The binding of $\mathrm{T}_{3}$ to the TR molecule alters its conformation in such a way that the corepressor complex is replaced by a coactivator complex. The essential role played by SRC-1 in $\mathrm{T}_{3}$ action mediated by TRs has been demonstrated by the finding that SRC-1 knockout mice exhibit thyroid hormone resistance in peripheral tissues as a major phenotype (Weiss et al. 1999). Coactivators p/CAF, p300, and SRC-1 possess histone acetylase activity and thus, modification of histones around the TRE promotes an open chromatin conformation allowing greater access for the basal transcriptional machinery (Harvey and Williams 2002). The thyroid hormone receptor activating proteins (TRAPs), $\mathrm{T}_{3}$-dependent interacting factors, have been shown to play a similar role as interacting factors with vitamin $\mathrm{D}_{3}$ receptor. 
Protein p160 of the SRC family interacts with TR when $\mathrm{T}_{3}$ binding occurs, but these proteins are subsequently replaced by the TRAP complexes to optimize transactivation (Ito and Roeder 2001; Harvey and Williams 2002). In general, $\mathrm{T}_{3}$-dependent transcriptional activity requires recruitment of both TRAP and p160 protein coactivator complexes to TR molecule. Protein p160 and TRAP coactivator complexes act in a sequential manner, p160 complexes act earlier than TRAP and this ordered recruitment may proceed for multiple cycles of association and dissociation, with multiple rounds of transcription occurring within each cycle (Metivier et al. 2006; Aranda et al. 2013).

\section{Cross-talk of nuclear thyroid hormone receptors with other signaling pathways}

Cross-talk between TRs and the second messenger pathways has also been previously demonstrated (Harvey and Williams 2002). Thyroid hormone action through their cognate nuclear receptors is potentiated by protein kinase A-dependent phosphorylation in a manner independent of the TRE structure, but dependent on the cell line studied (Leitman et al. 1996). Thyroid hormone antagonizes prolactin signaling during mammary gland development by the janus kinase 2 (JAK2)/signal transducer and activator of transcription 5 (STAT5) (FavreYoung et al. 2000; Harvey and Williams 2002). Also, a cross-talk between TR and LXR regulatory pathways has been demonstrated in a thyroid hormone resistance mouse model (Hashimoto et al. 2006). In addition, LXRalpha and TRbeta have been confirmed to exert their reciprocal cross-talk on ABCA1 gene promoter at the transcriptional level (Hashimoto and Mori 2010). Moreover, both TR and LXR are capable to interact with other nuclear receptors, as well (Xiao et al. 2010; Lu and Cheng 2010).

Cross-talk between the thyroid hormone signaling and regulatory pathways in cholesterol metabolism or metabolic pathways comprising fatty acid synthesis and beta-oxidation, has also been reported (Liu and Brent 2010).

\section{Action of thyroid hormone via TRs on mammalian tissues}

The genomic action of $\mathrm{T}_{3}$ is based on the interactions with TRs and further binding to TREs of a variety of specific downstream genes. Thus, the transcriptional control via nuclear TRs represents the direct action of thyroid hormones (Glass and Holloway 1990; Liu et al. 2019).
In 1967, Refetoff was the first who demonstrated the resistance to thyroid hormones (RTH), which is characterized by reduced or impaired sensitivity of tissues to the actions of thyroid hormone. Later, it has been demonstrated that RTH syndrome is an autosomal dominant or recessive genetic disease caused by mutation of either nuclear receptor TRalpha or TRbeta (Refetoff et al. 2014; Tang et al. 2016; Sun et al. 2020). The RTH syndrome is normally inherited in autosomal dominant manner and is predominantly due to heterozygous mutations in TRbeta molecule (Chatterjee 1997; Refetoff and Dumitrescu 2007). Defects in any of the processes linked with thyroid hormone genomic actions give rise to distinct disease entities, collectively called thyroid hormone signaling disorders, and heterozygous mutations of TRbeta are the most common genetic cause of the RTH (Visser 2020). Mutations in TR molecule affecting the $T_{3}$ ligand binding domain interfere with $\mathrm{T}_{3}$ binding to $\mathrm{TR}$ and have a dominant negative effect on the $\mathrm{T}_{3}$ action, which means that TR molecules remain stably bound to the TREs in the repressive $\mathrm{T}_{3}$-free form, not allowing $\mathrm{T}_{3}$ genomic action (Yen 2003; Giammanco et al. 2020).

The $\mathrm{T}_{3}$ regulates the type 1 iodothyronine deiodinase mRNA in rat liver (Berry et al. 1990; Maia et al. 1995), which is one of the best-known thyroid hormone target genes (Koenig 2005; Flamant et al. 2006), and also increases type 2 iodothyronine deiodinase mRNA levels in rat brown adipocytes, the enzymes, which take part in the conversion of $\mathrm{T}_{4}$ to $\mathrm{T}_{3}$ (Martinez-deMena et al. 2002; Viguerie and Langin 2003). The $T_{3}$ plays a crucial role in the development of brain, acting on migration and differentiation of neural and glial cells, synaptogenesis, and myelination (Bernal and Nunez 1995; Bernal 2002, 2007). Hypothyroidism during the neonatal period of development causes mental retardation and a number of neurological defects (Viguerie and Langin 2003). TR isoforms, which are encoded by the TRalpha and TRbeta genes, are expressed in the brain, with the most common being TRalphal (Bernal 2007). In the cerebellum, TRalphal is predominantly expressed in the granular cell layer, whereas Purkinje cells predominantly express TRbetal (Morte et al. 2002; Bernal 2007). In the rat developing brain, the early phase of synaptogenesis is associated with a $\mathrm{T}_{3}$ dependent expression of tubulin and actin (Poddar et al. 1996). Later on, it has been reported that $\mathrm{T}_{3}$ regulates tubulin expression in mammalian liver, as well (Vallejo et al. 2005). $\mathrm{T}_{3}$ was also found to regulate adult hippocampal neurogenesis, a process involved in functions such as learning, memory, and mood 
regulation (Desouza et al. 2005; Montero-Pedrazuela et al. 2006; Pascual and Aranda 2013).

The $\mathrm{T}_{3}$ exerts significant effects on the cardiovascular systems and plays an important role in cardiac development, function and the maintenance of a normal cardiac physiology (Dillmann 2002; Kahaly and Dillmann 2005). Alterations in the thyroid status markedly affect cardiac contractile and electrical activity. $\mathrm{T}_{3}$ has a strong positive effect on the speed and force of the systolic contraction and the effect on the duration of diastolic relaxation in the heart (Mintz et al. 1991). $\mathrm{T}_{3}$ affects the cardiac action by exerting a direct effect on cardiac myocytes through binding to nuclear TRs. A higher number of nuclear TRs was demonstrated in cardiac myocytes in comparison with cardiac fibroblasts that contain about one tenth of TRs present in cardiac myocytes (Dillmann 2002). Multiple thyroid hormone effects are mediated by both TRalpha and TRbeta, whereas the TRalpha was demonstrated to be the predominant isoform in the heart. Hypothyroidism is distinguished by systolic and diastolic dysfunctions with reduced force and slowed relaxation, whereas hyperthyroidism causes augmenting heart rate and producing tachycardia (Dillmann 2010; Pascual and Aranda 2013). Actually, an impact of altered thyroid status on both the occurrence and recurrence of cardiac arrhythmias, predominantly atrial fibrillation, has been recently summarized (Tribulova et al. 2020). Cardiac myosin heavy chains are under control of $\mathrm{T}_{3}$, which stimulates expression of the alpha-myosin heavy chain gene and inhibits beta-myosin heavy chain mRNA production both in vivo and in cultured heart cells (Gustafson et al. 1987; Morkin et al. 1991, 1993). In mammals, $\mathrm{T}_{3}$ via TRs regulates the cardiac beta-adrenergic receptor-adenylate cyclase system by controlling the rate of transcription of the betal-adrenergic receptor gene in a tissue-specific manner (Bahouth 1991), predominantly during a critical development period (Metz et al. 1996).

Skeletal muscle contractile function and myogenesis are affected by $\mathrm{T}_{3}$ through TRalpha and TRbeta, but TRalpha appears to represent the major isoform mediating the effect of thyroid hormone. $\mathrm{T}_{3}$ stimulates skeletal muscle growth by increasing number and diameter of the muscle fibers (Sugie and Verity 1985; Bloise et al. 2018).

The $\mathrm{T}_{3}$ is essential for the bone development and growth. In adults, the bone mass maintenance is also under the control of thyroid hormone and physiological role of the thyroid hormone-activating enzyme type 2 iodothyronine deiodinase in the optimization of bone mineralization and strength has been demonstrated (Waung et al. 2012; Lademann et al. 2020). The thyroid hormone controls skeletal development and growth, moreover, $\mathrm{T}_{3}$ plays a role in adult bone mineralization, as well. TRalphal and TRbeta1 isoforms are expressed in bone tissue, although TRalphal is expressed at much higher concentration than TRbetal, and in bone, TRalphal is considered to be a predominant mediator of thyroid hormone action (Freitas et al. 2005; Beber et al. 2009). Both TRalphal and TRbetal are expressed in chondrocytes, bone marrow stromal cells, osteoblasts, osteocytes, and osteoclasts (Gogakos et al. 2010; Pascual and Aranda 2013).

The $\mathrm{T}_{3}$ acting via its cognate receptors is indispensable for the proper functioning of the female reproductive system, since it modulates the metabolism and development of ovarian, uterine, and placental tissues (Evans et al. 1983; Maruo et al. 1992; James et al. 2007; Silva et al. 2018). Thyroid dysfunction is associated with several physiological and behavioral alterations, comprising reproductive disorders in women (Choksi et al. 2003). Nuclear TR isoforms, TRalphal and TRbeta1, are present in the placenta, and their expression increases with fetal age (Chan and Kilby 2000; Silva et al. 2018).

The $\mathrm{T}_{3}$ produces profound effects through its cognate receptors on the developing testis, affecting spermatogenesis, steroidogenesis, testis size, reproductive hormones and fertility. $\mathrm{T}_{3}$ acts on testis in multiple ways and exerts its effect on different cell types, including Leydig and Sertoli cells and germ cells (Hernandez 2018; La Vignera and Vita 2018; Hernandez and Martinez 2020).

The $\mathrm{T}_{3}$ plays an important role in maintaining the hepatic homeostasis. The first evidence that nuclei from rat liver possess a set of receptor sites, which exhibit specificity for $\mathrm{T}_{3}$ was demonstrated nearly a half of the century ago (Oppenheimer et al. 1972). Liver tissue expresses both TRalpha and TRbeta, and in adult liver, TRbeta is the predominant isoform (Flores-Morales et al. 2002; Yen et al. 2003; Ritter et al. 2020), which plays a key role in liver cell proliferation (Pascual and Aranda 2013). Thyroid hormone affects the intermediary metabolism and it influences the transcriptional and posttranscriptional regulation of rat hepatic 3-hydroxy-3-methylglutaryl-coenzyme A reductase (HMG-CoA) (Simonet and Ness 1988). Also, the effect of $\mathrm{T}_{3}$ on the chromatin structure and expression of the malic enzyme gene in hepatocytes has been confirmed (Usala et al. 1988b; Petty et al. 1989; Yin et al. 2005). Microarray analyses identified many novel gene candidates responsive to $\mathrm{T}_{3}$ in liver affecting lipid metabolism, apoptosis and inflamma- 
tory responses (Flores-Morales et al. 2002; Yen et al. 2003; Viguerie and Langin 2003; Flamant et al. 2006).

The $\mathrm{T}_{3}$ influences renal development, kidney hemodynamics, glomerular filtration rate, and sodium and water homeostasis (Iglesias et al. 2017) and affects a variety of co-transport systems in the renal tubule, including the $\mathrm{Na}-\mathrm{P}$ co-transporter, $\mathrm{Na}^{+} / \mathrm{H}^{+}$exchanger, and the $\mathrm{Na}^{+} / \mathrm{K}^{+}$ATPase in proximal convoluted tubule (Basu and Mohapatra 2012). Thyroid hormone has also been reported to affect the expression of atrial natriuretic factor at both the mRNA and the protein level in hypothyroid, euthyroid, and hyperthyroid rats (Ladenson et al. 1988), and is capable to induce $\mathrm{Na}^{+} / \mathrm{K}^{+}$ATPases and sarcoplasmic $\mathrm{Ca}^{2+}$-ATPases gene expression in a tissue-dependent manner (Gick et al. 1988; Gick and Ismail-Beigi 1990; Viguerie and Langin 2003).

In pancreas, the $\mathrm{T}_{3}$ stimulates beta-cell proliferation and survival (Verga Falzacappa et al. 2006). $\mathrm{T}_{3}$ bound to TRalpha takes part in activation of the cyclin D1/cyclin-dependent kinase/retinoblastoma protein/E2F pathway, along with cell cycle progression and cell proliferation (Pascual and Aranda 2013).

The $\mathrm{T}_{3}$ controls the intestinal development and homeostasis. In the intestinal epithelium, which is physiologically rapidly regenerated, the importance of the TRalphal receptor has been demonstrated, notably in controlling the postnatal intestinal maturation (Frau et al. 2017). Both TRalpha and TRbeta are expressed in intestinal epithelial cells, but proliferation of epithelial cells depends predominantly on the TRalpha1, which is involved in the regulation of cell cycle control genes and of the Wnt/beta-catenin pathway, playing a role as a key modulator of cell proliferation in the intestinal epithelium (Plateroti et al. 1999, 2001; Pascual and Aranda 2013).

The skin, among the other target organs, is markedly influenced by thyroid hormone, which is essential for skin homeostasis, and skin diseases are frequently associated with an altered thyroid status (Mancino et al. 2021). By binding of $\mathrm{T}_{3}$ to their cognate nuclear TRs (TRalpha and TRbeta), $\mathrm{T}_{3}$ regulates epidermal cell proliferation, differentiation, and homeostasis (Contreras-Jurado et al. 2011; Antonini et al. 2013; Pascual and Aranda 2013).

The $\mathrm{T}_{3}$ is also known to cause a rapid increase in the translational activity of a specific mRNA coding for a protein designated "Spot 14" (Jump et al. 1984; Liaw and Towle 1984). Later on, the "Spot 14" has been shown to play a key role in the tissue-specific regulation of lipid metabolism. It is a $17-\mathrm{kDa}$ protein expressed in lipogenic tissues and was postulated to play a role in thyroid hormone stimulation of lipo- genesis (Cunningham et al. 1998; Campbell et al. 2003). Human "Spot 14" protein interacts physically and functionally with the nuclear TR and it acts as a positive or negative cofactor to regulate malic enzyme gene expression induced by $\mathrm{T}_{3}$ (Chou et al. 2007). Expression of $\mathrm{T}_{3}$ responsive "Spot 14" is enhanced during differentiation of human adipocytes and its expression is down-regulated in obese subjects (Ortega et al. 2010).

The constitutive $63 \mathrm{kDa}$ keratin genes involved in the Xenopus laevis development belong to genes activated by $\mathrm{T}_{3}$ (Mathisen and Miller 1989). $\mathrm{T}_{3}$ stimulates growth hormone $(\mathrm{GH})$ gene transcription in rat pituitary tumor cells at both the mRNA and the protein level (Glass et al. 1987; Brent et al. 1989; Norman et al. 1989). $T_{3}$ acts via its cognate receptors by forming a more active transcription complex, which stimulates the level of GH gene expression (Ye et al. 1988).

In spite of the fact that a number of data clearly confirm the genomic action of $\mathrm{T}_{3}$, many novel gene candidates, responsive to $\mathrm{T}_{3}$ and acting via TRs, remain to be discovered and their role clarified.

\section{Nuclear thyroid hormone receptors and cancer}

A number of studies have demonstrated the presence of either qualitative alterations, representing mutations or quantitative changes in the expression of TR genes in different types of human neoplasias. Qualitative alterations on the TR gene represent gross chromosomal or minor mutations, comprising deletions, aberrant splicing or point mutations. Quantitative changes involve the data on increased or decreased rate of expression of TRalpha and TRbeta genes (Gonzalez-Sancho et al. 2003). In human thyroid papillary carcinoma, the expression levels of TRalpha mRNA and TRbeta mRNA were significantly lower when compared to normal human thyroid tissue (Puzianowska-Kuznicka et al. 2002). Our results support these findings, moreover, it has been reported that decreased expression levels of both TRalpha and TRbeta mRNA in human thyroid papillary carcinoma with co-existent autoimmune thyroiditis were seen when compared to thyroid papillary tumor tissue of patients without autoimmune thyroiditis (Macejova et al. 2019). Moreover, mutation on TRbeta molecule plays a critical role in thyroid cancer development, as well (Liu et al. 2019). Functional TRs have been previously demonstrated in both thyroid carcinoma tissues and different thyroid tumor cell lines (Schmutzler et al. 1988). Contrary, investigation on TRs by the EMSA method in both the human benign toxic adenomas 
and benign cold nodules has shown a significant increase of TRs level in toxic adenomas when compared to normal thyroid tissue from the same patient (Brtko et al 2002).

Distribution of TRs during the cell cycle in mouse leukemia cells has been demonstrated. It has been shown that processes involving TRs promotion in cell nuclei are operative within the late $G_{1}$ and $S$ phases of the cell cycle, and thus the increase in $\mathrm{T}_{3}$ receptor concentration in the nuclei is in a positive correlation with the number of cells in the S compartment of the cell cycle (Filipcik et al. 1992). In vitro data, indicating connections between TRs and cell cycle regulators and oncogenes, suggest that both TRalpha and TRbeta may be involved in human cancer (GonzalezSancho et al. 2003). In $\mathrm{GH}_{4} \mathrm{C}_{1}$ rat pituitary tumor cells, biological effects of thyroid hormone depending on TRs occupancy by $\mathrm{T}_{3}$, have been demonstrated, as well (Filipcik et al. 1998).

Reduced expression of TRs in tumor tissue and/or alterations in TR genes are considered to be common events in human cancer and have been previously comprehensively reviewed (Aranda et al. 2009; FontDiaz et al. 2020). Reduced expression, anomalous cellular localization, and/or alterations of the TRbeta gene occur in many types of human tumors (Aranda et al. 2009). It has been shown that TRbeta may function as a tumor suppressor in mouse models of metastatic follicular thyroid carcinoma (Zhu et al. 2010) or in mammary tumors (Guigon et al. 2011; Font-Diaz et al. 2020) and control tumor cell proliferation and cancer cell defense pathways. In breast cancer, the transcription of the pro-apoptotic Bcl-2-associated death promoter (Bad) gene and X-linked inhibitor of apoptosis (XIAP) gene are downregulated by $\mathrm{T}_{3}$ (Liu et al. 2019). In normal breast tissue, TRalphal is expressed during the pubescent, pregnancy and weaning period, and TRbetal is primarily expressed during lactation (Anguiano et al. 2004). TRbetal is associated with $\mathrm{T}_{3}$ metabolic activity, while TRalpha1 plays an important role in the cell differentiation and apoptosis (Yen 2001; Macejova et al. 2005). Both TR isoforms may also have an opposite role in breast cancer, whereas TRalpha expression is high and TRbeta expression is missing (Jerzak et al. 2015, 2018; Font-Diaz et al. 2020). Decreased TRbeta expression, due to silencing of the corresponding gene, has been found in human cancer, including breast, lung, and thyroid carcinoma (Joseph et al. 2007). On the other hand, the expression of the TRbeta gene could also be repressed via microRNAs regulatory mechanisms in papillary thyroid cancer (Jadzewski et al. 2011; Kim and Cheng 2013).
The thyroid hormones modulate the expression of specific microRNAs (miRNAs) and their mRNA targets in different cell types and organs, and miRNA regulation is involved in the effects of TRs on cell proliferation and cancer (Aranda 2021). TRbeta has been found to induce the transcription of miRNAs, miR-424 and miR503, which belong to the miR-16 family, known for their capacity to down-regulate proliferation, migration and invasion of cancer cells. Induction of these miRNAs mediates some of the antiproliferative and antimetastatic actions of $\mathrm{T}_{3}$ (Ruiz-Llorente et al. 2014; Font-Diaz et al. 2020; Aranda 2021).

New directions in the field of TRs investigation include questions regarding the cancer progression pathways, which show considerable variability and complexity. At present, the $\mathrm{T}_{3}$ acting via TRs has not yet been established as a critical risk or prognostic factor for cancer. Both TR isoforms, which are involved in various tumor types and stages of development support the hypothesis on possible dual role of TRs in human cancers, either as an oncogene or a tumor suppressor. Reduced TR isoforms expression and/or alterations in TR genes are common events in human cancer (Gonzalez-Sancho et al. 2003; Aranda et al. 2009; Liu et al. 2019). The demonstration of a tumor suppressor role for the TRbeta isoform opens new therapeutic perspectives for the antiproliferative, differentiation-promoting function of the TRbeta isoform and its native cognate ligand $\mathrm{T}_{3}$ as well as for TRbeta isoform-selective novel biologically active $\mathrm{T}_{3}$ analogs (Kohrle 2004). Several mechanisms involved in the antitumorigenic and antimetastatic effects of TRbeta have been reported. The $\mathrm{T}_{3}$ induces cellular senescence in the liver, a mechanism that is believed to act as a first barrier against cellular transformation and tumor development (Collado and Serrano 2010), which is mediated by $\mathrm{T}_{3}$ binding to TRbeta, and not to TRalpha (Zambrano et al. 2014; Font-Diaz et al. 2020). The detailed role of functional significance of $\mathrm{T}_{3}$ and its cognate TRbeta in tumors as well as mechanisms of antitumorigenic and antimetastatic actions of the TRbeta in human cancers has yet to be elucidated.

\section{Concluding remarks}

The cell nucleus represents a major site of the thyroid hormone action. The thyroid hormone receptors belong to a group of known 48 human nuclear receptors, which are ligand-activated, transcription-modulating proteins affecting transcriptional responses in target genes. 
The $\mathrm{T}_{3}$, via its cognate TRs, plays a crucial role in the development of brain, it modulates differentiation of neural and glial cells, synaptogenesis, and myelination. $\mathrm{T}_{3}$ through TRs regulates adult hippocampal neurogenesis, a process involved in functions such as learning, memory, and mood regulation. The $\mathrm{T}_{3}$ acts on the cardiovascular systems and via TRs plays an important role in cardiac development, function and the maintenance of the normal cardiac physiology. Skeletal muscle contractile function and myogenesis are affected by $\mathrm{T}_{3}$ through TRs. The $T_{3}$ is essential for the bone development and growth. The $\mathrm{T}_{3}$ bound to TRs controls skeletal development and growth and bone mineralization. The $\mathrm{T}_{3}$ acting via its TRs is also essential for the proper functioning of the female and male reproductive system. $T_{3}$ bound to TRs plays an important role in maintaining the hepatic homeostasis, it regulates expression of iodothyronine deiodinase and affects the intermediary and lipid metabolism. The $\mathrm{T}_{3}$ via its TRs influences the renal development and kidney homeostasis, intestinal development and homeostasis and also plays a role in the stimulation of beta-cell proliferation and survival in pancreas. The skin is also influenced by $\mathrm{T}_{3}$, which upon its binding to TRs regulates the epidermal cell proliferation, differentiation, and homeostasis.

The canonical pathway of $T_{3}$ signaling via nuclear TRs is considered to be sufficient to explain the most of the pleiotropic effects of $T_{3}$ in physiology, however, a number of questions still remains to be answered (Flamant 2016). Among the number of unanswered questions is the report demonstrating that mutations in the C-terminal domain of the TR molecule, located far from the ligand-binding pocket, reduce the affinity for $\mathrm{T}_{3}$ binding (Marimuthu et al. 2002; Flamant 2016). Allosteric properties of RXR/TR complexes might also be relevant for the forthcoming studies of thyroid hormone disruptors, as several of environment affecting chemicals are thought to be TR ligands (Giera et al. 2011; Flamant 2016). Many additional unanswered questions regarding the properties of TRs in $\mathrm{T}_{3}$ action have been thoroughly reviewed by Frederic Flamant (2016).

\section{Acknowledgment}

The work was supported by the Slovak Research and Development Agency APVV-15-372, APVV-190093 grants, SAV-18-16 and VEGA 2/0116/21 grants.

\section{References}

Anguiano B, Rojas-Huidobro R, Delgado G, Aceves C. Has the mammary gland a protective mechanism against overexposure to triiodothyronine during the peripartum period? The prolactin pulse down-regulates mammary type I deiodinase responsiveness to norepinephrine. J Endocrinol 183, 267-277, 2004.

Antonini D, Sibilio A, Dentice M, Missero C. An intimate relationship between thyroid hormone and skin: regulation of gene expression. Front Endocrinol (Lausanne) 4, 104, 2013.

Aranda A, Pascual A. Nuclear hormone receptors and gene expression. Physiol Rev 81, 1269-1304, 2001.

Aranda A, Martinez-Iglesias O, Ruiz-Llorente L, Garcia-Carpizo V, Zambrano A. Thyroid receptor: roles in cancer. Trends Endocrinol Metab 20, 318-324, 2009.

Aranda A, Alonso-Merino E, Zambrano A. Receptors of thyroid hormones. Pediatr Endocrinol Rev 11, 2-13, 2013.

Aranda A. MicroRNAs and thyroid hormone action. Mol Cell Endocrinol 525, 111175, 2021.

Bahouth SW. Thyroid hormones transcriptionally regulate the beta 1-adrenergic receptor gene in cultured ventricular myocytes. J Biol Chem 266, 15863-15869, 1991.

Baker ME, Vaughn DA, Fanestil DD. Inhibition by protease inhibitors of binding of adrenal and sex steroid hormones. J Supramol Struct 9, 421-426, 1978.

Barettino D, Vivanco Ruiz MM, Stunnenberg HG. Characterization of the ligand-dependent transactivation domain of thyroid hormone receptor. EMBO J 13, 3039-3049, 1994.

Barsano CP, Iqbal Z, Pullen GL, Munoz BE, Singh SP. Tissue-specific differences in the compartmentalization of rat nuclear triiodothyronine receptors. Acta Endocrinol (Copenh) 122, 181-190, 1990.

Basu G, Mohapatra A. Interactions between thyroid disorders and kidney disease. Indian J Endocrinol Metab 2, 204-213, 2012.

Beber EH, Capelo LP, Fonseca TL, Costa CC, Lotfi CF, Scanlan TS, Gouveia CH. The thyroid hormone receptor (TR) beta-selective agonist GC-1 inhibits proliferation but induces differentiation and TR beta mRNA expression in mouse and rat osteoblast-like cells. Calcif Tissue Int 84, 324-333, 2009.

Benbrook D, Pfahl M. A novel thyroid hormone receptor encoded by a cDNA clone from a human testis library. Science 238(4828), 788-791, 1987. 
Bernal J, Nunez J. Thyroid hormones and brain development. Eur J Endocrinol 133, 390-398, 1995.

Bernal J. Action of thyroid hormone in brain. J Endocrinol Invest 25, 268-288, 2002.

Bernal J. Thyroid hormone receptors in brain development and function. Nat Clin Pract Endocrinol Metab 3, 249259, 2007.

Berry MJ, Kates AL, Larsen PR. Thyroid hormone regulates type I deiodinase messenger RNA in rat liver. Mol Endocrinol 4, 743-748, 1990

Bloise FF, Cordeiro A, Ortiga-Carvalho TM. Role of thyroid hormone in skeletal muscle physiology. J Endocrinol 236, R57-R68, 2018.

Brent GA, Larsen PR, Harney JW, Koenig RJ, Moore DD. Functional characterization of the rat growth hormone promoter elements required for induction by thyroid hormone with and without a co-transfected beta type thyroid hormone receptor. J Biol Chem 264, 178-182, 1989.

Brtko J, Knopp J, DeGroot LJ. Physiochemical factors influencing the stability of solubilized liver nuclear receptor3,5,3'-triiodothyronine complex in vitro. Endocrinol Exp 21, 251-256, 1987.

Brtko J, Knopp J. Binding parameters of rat liver nuclear receptors for $\mathrm{T}_{3}$ after partial hepatectomy or bilateral adrenalectomy and serum $\mathrm{T}_{4}$ and $\mathrm{T}_{3}$ levels. Endocr Exper 22, 211-220, 1988.

Brtko J, Ichikawa K, DeGroot LJ. Rat liver nuclear receptors for thyroid hormone: Binding characteristics after stabilization and storage. Folia Biologica (Praha) 39, 69-77, 1992a.

Brtko J, Filipcik P, Knopp J, Sedlakova V, Rauova L. Thyroid hormone responsiveness of the L1210 murine leukemia cell line. Acta Endocrinol (Copenh) 126, 374-377, 1992b.

Brtko J, Knopp J, Baker ME. Inhibition of 3,5,3'-triiodothyronine binding to its receptor in rat liver by protease inhibitors and substrates. Mol Cell Endocrinol 93, 81-86, 1993.

Brtko J, Pascual A, Aranda A. 3,5,3'-tiiodothyronine nuclear receptors and their role in the thyroid hormone action. Endocr Exper 28, 707-115,1994.

Brtko J, Bobalova J, Podoba J, Schmutzler C, Kohrle J. Thyroid hormone receptors and type I iodothyronine 5'-deiodinase activity of human thyroid toxic adenomas and benign cold nodules. Exp Clin Endocrinol Diabetes 110, 166-170, 2002.

Brtko J, Dvorak Z. Role of retinoids, rexinoids and thyroid hormone in the expression of cytochrome p450 enzymes. Curr Drug Metab 12, 71-88, 2011.

Brtko J, Dvorak Z. Natural and synthetic retinoid X receptor ligands and their role in selected nuclear receptor action. Biochimie 179, 157-168, 2020.

Campbell MC, Anderson GW, Mariash CN. Human spot 14 glucose and thyroid hormone response: characterization and thyroid hormone response element identification. Endocrinology 144, 5242-5248, 2003.

Castillo AI, Sanchez-Martinez R, Moreno JL, Martinez-Iglesias OA, Palacios D, Aranda A. A permissive retinoid X receptor/thyroid hormone receptor heterodimer allows stimulation of prolactin gene transcription by thyroid hormone and 9-cis-retinoic acid. Mol Cell Biol 24, 502-513, 2004.

Chan S, Kilby MD. Thyroid hormone and central nervous system development. J Endocrinol 165, 1-8, 2000.

Chatterjee VK. Resistance to thyroid hormone. Horm Res 48 Suppl 4, 43-46, 1997.

Choksi NY, Jahnke GD, St Hilaire C, Shelby M. Role of thyroid hormones in human and laboratory animal reproductive health. Birth Defects Res B Dev Reprod Toxicol 68, 479-491, 2003.

Chou WY, Cheng YS, Ho CL, Liu ST, Liu PY, Kuo CC, Chang HP, Chen YH, Chang GG, Huang SM. Human spot 14 protein interacts physically and functionally with the thyroid receptor. Biochem Biophys Res Commun 357, $133-138,2007$.

Collado M, Serrano M. Senescence in tumours: evidence from mice and humans. Nat Rev Cancer 10, 51-57, 2010.

Contreras-Jurado C, Garcia-Serrano L, Gomez-Ferreria M, Costa C, Paramio JM, Aranda A. The thyroid hormone receptors as modulators of skin proliferation and inflammation, J Biol Chem 286, 24079-24088, 2011.

Cunningham BA, Moncur JT, Huntington JT, Kinlaw WB. "Spot 14" protein: a metabolic integrator in normal and neoplastic cells. Thyroid 8, 815-825, 1998.

Dahlman-Wright K, Grandien K, Nilsson S, Gustafsson JA, Carlstedt-Duke J. Protein-protein interactions between the DNA-binding domains of nuclear receptors: influence on DNA-binding. J Steroid Biochem Mol Biol 45, 239-250, 1993.

DeGroot LJ, Torresani J. Triiodothyronine binding to isolated liver cell nuclei. Endocrinology 96, 357-359, 1975.

DeGroot LJ, Coleoni AH, Rue PA, Seo H, Martino E, Refetoff S. Reduced nuclear triiodothyronine receptors in starvation-induced hypothyroidism. Biochem Biophys Res Commun 79, 173-178, 1977a.

DeGroot LJ, Rue P, Robertson M, Bernal J, Scherberg N. Triiodothyronine stimulates nuclear RNA synthesis. Endocrinology 101, 1690-1700, 1977b. 
Desouza LA, Ladiwala U, Daniel SM, Agashe S, Vaidya RA, Vaidya VA. Thyroid hormone regulates hippocampal neurogenesis in the adult rat brain. Mol Cell Neurosci 29, 414-426, 2005.

Dillmann WH, Schwartz HL, Oppenheimer JH. Selective alternation in hepatic enzyme response after reduction of nuclear triiodothyronine receptor sites by partial hepatectomy and starvation. Biochem Biophys Res Commun 80, 259-266, 1978.

Dillmann WH. Cellular action of thyroid hormone on the heart. Thyroid 12, 447-452, 2002.

Dillmann WH. Cardiac hypertrophy and thyroid hormone signaling. Heart Fail Rev 15, 125-132, 2010.

Eberhardt NL, Valcana T, Timiras PS. Triiodothyronine nuclear receptors: An in vitro comparison of the binding of triiodothyronine to nuclei of adult rat liver, cerebral hemisphere and anterior pituitary. Endocrinology 102, 556-561, 1978.

Evans RW, Farwell AP, Braverman LE. Nuclear thyroid hormone receptor in the rat uterus. Endocrinology 113, 1459-1463, 1983.

Evans RM. The steroid and thyroid hormone receptor superfamily. Science 240, 889-895, 1988.

Evans RM, Mangelsdorf DJ. Nuclear receptors, RXR \& the Big Bang. Cell 157, 255-266, 2014.

Favre-Young H, Dif F, Roussille F, Demeneix BA, Kelly PA, Edery M, de Luze A. Cross-talk between signal transducer and activator of transcription (Stat5) and thyroid hormone receptor-beta 1 (TRbeta1) signaling pathways. Mol Endocrinol 14, 1411-1424, 2000.

Filipcik P, Brtko J, Rauova L, Sedlakova V. Distribution of triiodothyronine nuclear receptors during the cell cycle in mouse leukemia cells. Folia Biol (Praha) 38, 332-339, 1992.

Filipcik P, Strbak V, Brtko J. Thyroid hormone receptor occupancy and biological effects of 3,5,3,-L-triiodothyronine (T3) in $\mathrm{GH}_{4} \mathrm{C}_{1}$ rat pituitary tumour cells. Physiol Res 47, 41-46, 1998.

Flamant F, Baxter JD, Forrest D, Refetoff S, Samuels H, Scanlan TS, Vennstrom B, Samarut J. International Union of Pharmacology. LIX. The pharmacology and classification of the nuclear receptor superfamily: Thyroid hormone receptors. Pharmacol Rev 58, 705-711, 2006.

Flamant F. Futures challenges in thyroid hormone signaling research. Front Endocrinol (Lausanne) 7, 58, 2016.

Flores-Morales A, Gullberg H, Fernandez L, Stahlberg N, Lee NH, Vennstrom B, Norstedt G. Patterns of liver gene expression governed by TRbeta. Mol Endocrinol 16, 1257-1268, 2002.

Font-Diaz J, Jimenez-Panizo A, Caelles C, Vivanco MD, Perez P, Aranda A, Estebanez-Perpina E, Castrillo A, Ricote M, Valledor AF. Nuclear receptors: Lipid and hormone sensors with essential roles in the control of cancer development. Semin Cancer Biol S1044-579X(20)30267-4, 2020. Epub ahead of print.

Frau C, Godart M, Plateroti M. Thyroid hormone regulation of intestinal epithelial stem cell biology. Mol Cell Endocrinol 459, 90-97, 2017.

Freitas FR, Capelo LP, O’Shea PJ, Jorgetti V, Moriscot AS, Scanlan TS, Williams GR, Zorn TM, Gouveia CH. The thyroid hormone receptor beta-specific agonist GC-1 selectively affects the bone development of hypothyroid rats. J Bone Miner Res 20, 294-304, 2005.

Germain P, Chambon P, Eichele G, Evans RM, Lazar MA, Leid M, De Lera AR, Lotan R, Mangelsdorf DJ, Gronemeyer H. International Union of Pharmacology. LXIII. Retinoid X receptors. Pharmacol Rev 58, 760-772, $2006 \mathrm{a}$.

Germain P, Staels B, Dacquet C, Spedding M, Laudet V. Overview of nomenclature of nuclear receptors. Pharmacol. Rev 58, 685-704, 2006b.

Giammanco M, Di Liegro CM, Schiera G, Di Liegro I. Genomic and non-genomic mechanisms of action of thyroid hormones and their catabolite 3,5-diiodo-L-thyronine in mammals. Int J Mol Sci 21, 4140, 2020.

Gick GG, Ismail-Beigi F, Edelman IS. Thyroidal regulation of rat renal and hepatic Na,K-ATPase gene expression. J Biol Chem 263, 16610-16618, 1988.

Gick GG, Ismail-Beigi F. Thyroid hormone induction of $\mathrm{Na}(+)-\mathrm{K}(+)$-ATPase and its $\mathrm{mRNAs}$ in a rat liver cell line. Am J Physiol 258, C544-C551, 1990.

Giera S, Bansal R, Ortiz-Toro TM, Taub DG, Zoeller RT. Individual polychlorinated biphenyl (PCB) congeners produce tissue- and gene-specific effects on thyroid hormone signaling during development. Endocrinology 152, 2909-2919, 2011.

Giguere V, Ong ES, Segui P, Evans RM. Identification of a receptor for the morphogen retinoic acid. Nature 330, 624-629, 1987.

Giguere V, Yang N, Segui P, Evans RM. Identification of a new class of steroid hormone receptors. Nature 331, 91-94, 1988.

Glass CK, Franco R, Weinberger C, Albert VR, Evans RM, Rosenfeld MG. A c-erb-A binding site in rat growth hormone gene mediates trans-activation by thyroid hormone. Nature 329(6141), 738-741, 1987. 
Glass CK, Holloway JM, Devary OV, Rosenfeld MG. The thyroid hormone receptor binds with opposite transcriptional effects to a common sequence motif in thyroid hormone and estrogen response elements. Cell 54, 313-323, 1988.

Glass CK, Holloway JM. Regulation of gene expression by the thyroid hormone receptor. Biochim Biophys Acta 1032, 157-176, 1990.

Glass CK. Some new twists in the regulation of gene expression by thyroid hormone and retinoic acid receptors. J Endocrinol 150, 349-357, 1996.

Green S, Chambon P. Nuclear receptors enhance our understanding of transcription regulation. Trends Genet 4, 309-314, 1988.

Gogakos AI, Duncan Bassett JH, Williams GR. Thyroid and bone. Arch Biochem Biophys 503, 129-136, 2010.

Gonzalez-Sancho JM, Garcia V, Bonilla F, Munoz A. Thyroid hormone receptors/THR genes in human cancer. Cancer Lett 192, 121-132, 2003.

Gross J, Pitt-Rivers R. The identification of 3,5,3'-L-triiodothyronine in human plasma. Lancet 259, 439-441, 1952.

Guigon CJ, Kim DW, Willingham MC, Cheng SY. Mutation of thyroid hormone receptor-B in mice predisposes to the development of mammary tumors. Oncogene 30, 3384-3390, 2011.

Gustafson TA, Markham BE, Bahl JJ, Morkin E. Thyroid hormone regulates expression of a transfected alpha-myosin heavy-chain fusion gene in fetal heart cells. Proc Natl Acad Sci USA 84, 3122-3126, 1987.

Harington CR, Barger G. Chemistry of thyroxine: Constitution and synthesis of thyroxine. Biochem J 21, 169-183, 1927.

Harvey CB, Williams GR. Mechanism of thyroid hormone action. Thyroid 12, 441-446, 2002.

Hashimoto K, Cohen RN, Yamada M, Markan KR, Monden T, Satoh T, Mori M, Wondisford FE. Cross-talk between thyroid hormone receptor and liver $\mathrm{X}$ receptor regulatory pathways is revealed in a thyroid hormone resistance mouse model. J Biol Chem 281, 295-302, 2006.

Hashimoto K, Mori M. Crosstalk of thyroid hormone receptor and liver X receptor in lipid metabolism and beyond. Endocr J 58, 921-930, 2011.

Hernandez A. Thyroid hormone role and economy in the developing testis. Vitam Horm 106, 473-500, 2018.

Hernandez A, Martinez ME. Thyroid hormone action in the developing testis: intergenerational epigenetics. J Endocrinol 244, R33-R46, 2020.

Heyman RA, Mangelsdorf DJ, Dyck JA, Stein RB, Eichele G, Evans RM, Thaller C. 9-cis retinoic acid is a high affinity ligand for the retinoid X receptor. Cell 68, 397-406, 1992.

Horlein AJ, Naar AM, Heinzel T, Torchia J, Gloss B, Kurokawa R, Ryan A, Kamei Y, Soderstrom M, Glass CK, Rosenfeld MG. Ligand-independent repression by the thyroid hormone receptor mediated by a nuclear receptor co-repressor. Nature 377, 397-404. 1995.

Hubbard JR, Kalimi M. Influence of proteinase inhibitors on glucocorticoid receptor properties: recent progress and future perspectives. Mol Cell Biochem 66, 101-109, 1985.

Ichikawa K, Brtko J, DeGroot LJ, Hashizume K, Yamada T. Stabilization, accurate determination, and purification of rat liver nuclear thyroid hormone receptor. J Endocrinol 120, 237-243, 1989.

Iglesias P, Bajo MA, Selgas R, Diez JJ. Thyroid dysfunction and kidney disease: An update. Rev Endocr Metab Disord 18, 131-144, 2017.

Ito M, Roeder RG. The TRAP/SMCC/mediator complex and thyroid hormone receptor function. Trends Endocrinol Metab 12, 127-134, 2001.

Jazdzewski K, Boguslawska J, Jendrzejewski J, Liyanarachchi S, Pachucki J, Wardyn KA, Nauman A, de la Chapelle A. Thyroid hormone receptor beta (THRB) is a major target gene for microRNAs deregulated in papillary thyroid carcinoma (PTC). J Clin Endocrinol Metab 96, E546-E553, 2011.

James SR, Franklyn JA, Kilby MD. Placental transport of thyroid hormone. Best Pract Res Clin Endocrinol Metab 21, 253-264, 2007.

Jerzak KJ, Cockburn J, Pond GR, Pritchard KI, Narod SA, Dhesy-Thind SK, Bane A. Thyroid hormone receptor a in breast cancer: prognostic and therapeutic implications. Breast Cancer Res Treat 149, 293-301, 2015.

Jerzak KJ, Cockburn JG, Dhesy-Thind SK, Pond GR, Pritchard KI, Nofech Mozes S, Sun P, Narod SA, Bane A. Thyroid hormone receptor beta-1 expression in early breast cancer: a validation study. Breast Cancer Res Treat 171, 709-717, 2018.

Joseph B, Ji M, Liu D, Hou P, Xing M. Lack of mutations in the thyroid hormone receptor (TR) alpha and beta genes but frequent hypermethylation of the TRbeta gene in differentiated thyroid tumors. J Clin Endocrinol Metab 92, 4766-4770, 2007. 
Jump DB, Narayan P, Towle H, Oppenheimer JH. Rapid effects of triiodothyronine on hepatic gene expression. Hybridization analysis of tissue-specific triiodothyronine regulation of mRNAS14. J Biol Chem 259, 2789-2797, 1984.

Kahaly GJ, Dillmann WH. Thyroid hormone action in the heart. Endocr Rev 26, 704-728, 2005.

Kendall EC. The isolation in crystalline form of the compound containing iodine, which occurs in the thyroid: Its chemical nature and physiologic activity. J Am Med Assoc 64, 2042-2043, 1915.

Kim WG, Cheng SY. Thyroid hormone receptors and cancer. Biochim Biophys Acta 1830, 3928-3936, 2013.

Kliewer SA, Umesono K, Mangelsdorf DJ, Evans RM. Retinoid X receptor interacts with nuclear receptors in retinoic acid, thyroid hormone and vitamin D3 signalling. Nature 355, 446-449, 1992.

Koenig RJ, Warne RL, Brent GA, Harney JW, Larsen PR, Moore DD. Isolation of a cDNA clone encoding a biologically active thyroid hormone receptor. Proc Natl Acad Sci USA 85, 5031-5035, 1988.

Koenig RJ. Regulation of type 1 iodothyronine deiodinase in health and disease. Thyroid 15, 835-840, 2005.

Koerner D, Schwartz HL, Surks MI, Oppenheimer JH, Jorgensen EC. Binding of selected iodothyronine analogues to receptor sites of isolated rat hepatic nuclei: High correlation between structural requirements for nuclear binding and biological activity. J Biol Chem 250, 6417-6423, 1975.

Kohrle J. Guard your master: thyroid hormone receptors protect their gland of origin from thyroid cancer. Endocrinology 145, 4427-4429, 2004.

Krezel W, Ruhl R, de Lera AR. Alternative retinoid X receptor (RXR) ligands. Mol Cell Endocrinol 491, 110436, 2019.

La Vignera S, Vita R. Thyroid dysfunction and semen quality. Int J Immunopathol Pharmacol 32, 2058738418775241, 2018.

Lademann F, Tsourdi E, Hofbauer LC, Rauner M. Thyroid hormone actions and bone remodeling - The role of the Wnt signaling pathway. Exp Clin Endocrinol Diabetes 128, 450-454, 2020.

Ladenson PW, Bloch KD, Seidman JG. Modulation of atrial natriuretic factor by thyroid hormone: Messenger ribonucleic acid and peptide levels in hypothyroid, euthyroid, and hyperthyroid rat atria and ventricles. Endocrinology 123, 652-657, 1988.

Laudet V, Hanni C, Coll J, Catzeflis F, Stehelin D. Evolution of the nuclear receptor gene superfamily. EMBO J 11, 1003-1013, 1992.

Laudet V. Evolution of the nuclear receptor superfamily: Early diversification from an ancestral orphan receptor. J Mol Endocrinol 19, 207-226, 1997.

Leitman DC, Costa CH, Graf H, Baxter JD, Ribeiro RC. Thyroid hormone activation of transcription is potentiated by activators of cAMP-dependent protein kinase. J Biol Chem 271, 21950-21955, 1996.

Li D, Li T, Wang F, Tian H, Samuels HH. Functional evidence for retinoid X receptor (RXR) as a nonsilent partner in the thyroid hormone receptor/RXR heterodimer. Mol Cell Biol 22, 5782-5792, 2002.

Li H, Leo C, Schroen DJ, Chen JD. Characterization of receptor interaction and transcriptional repression by the corepressor SMRT. Mol Endocrinol 11, 2025-2037, 1997.

Liaw CW, Towle HC. Characterization of a thyroid hormone-responsive gene from rat. J Biol Chem 259, 7253-7260, 1984.

Liu YC, Yeh CT, Lin KH. Molecular functions of thyroid hormone signaling in regulation of cancer progression and anti-apoptosis. Int J Mol Sci 20, 4986, 2019.

Liu YY, Brent GA. Thyroid hormone crosstalk with nuclear receptor signaling in metabolic regulation. Trends Endocrinol Metab 21, 166-173, 2010.

Lu C, Cheng SY. Thyroid hormone receptors regulate adipogenesis and carcinogenesis via crosstalk signaling with peroxisome proliferator-activated receptors. J Mol Endocrinol 44, 143-154, 2010.

Maia AL, Kieffer JD, Harney JW, Larsen PR. Effect of 3,5,3'-Triiodothyronine (T3) administration on diol gene expression and T3 metabolism in normal and type 1 deiodinase-deficient mice. Endocrinology 136, 48424849, 1995.

Macejova D, Baranova M, Liska J, Brtko J. Expression of nuclear hormone receptors, their coregulators and type I iodothyronine 5'-deiodinase gene in mammary tissue of nonlactating and postlactating rats. Life Sci 77, 2584-2593, 2005.

Macejova D, Podoba J, Toporova L, Grigerova M, Kajo K, Machalekova K, Brtko J. Causal associations of autoimmune thyroiditis and papillary thyroid carcinoma: mRNA expression of selected nuclear receptors and other molecular targets. Oncol Lett 18, 4270-4277, 2019.

Mancino G, Miro C, Di Cicco E, Dentice M. Thyroid hormone action in epidermal development and homeostasis and its implications in the pathophysiology of the skin. J Endocrinol Invest 2021. Epub ahead of print. 
Mangelsdorf DJ, Ong ES, Dyck JA, Evans RM. Nuclear receptor that identifies a novel retinoic acid response pathway. Nature 345, 224-229, 1990.

Mangelsdorf DJ, Borgmeyer U, Heyman RA, Zhou JY, Ong ES, Oro AE, Kakizuka A, Evans RM. Characterization of three RXR genes that mediate the action of 9-cis retinoic acid. Genes Dev 6, 329-344, 1992.

Marimuthu A, Feng W, Tagami T, Nguyen H, Jameson JL, Fletterick RJ, Baxter JD, West BL. TR surfaces and conformations required to bind nuclear receptor corepressor. Mol Endocrinol 16, 271-286. 2002.

Marketos S, Eftychiadis A, Koutras DA. Thyroid diseases in the Byzantine era. J R Soc Med 83, 111-113, 1990.

Martinez-deMena R, Hernandez A, Obregon MJ. Triiodothyronine is required for the stimulation of type II 5'-deiodinase mRNA in rat brown adipocytes. Am J Physiol Endocrinol Metab 282, E1119-E1127, 2002.

Maruo T, Katayama K, Barnea ER, Mochizuki M. A role for thyroid hormone in the induction of ovulation and corpus luteum function. Horm Res 37, 12-18,1992.

Mathisen PM, Miller L. Thyroid hormone induces constitutive keratin gene expression during Xenopus laevis development. Mol Cell Biol 9, 1823-1831, 1989.

Mengeling BJ, Furlow JD. Pituitary specific retinoid-X receptor ligand interactions with thyroid hormone receptor signaling revealed by high throughput reporter and endogenous gene responses. Toxicol In Vitro 29, 1609-1618, 2015.

Metivier R, Reid G, Gannon F. Transcription in four dimensions: nuclear receptor-directed initiation of gene expression. EMBO reports 7, 161-167, 2006.

Metz LD, Seidler FJ, McCook EC, Slotkin TA. Cardiac alpha-adrenergic receptor expression is regulated by thyroid hormone during a critical developmental period. J Mol Cell Cardiol 28, 1033-1044, 1996.

Mintz G, Pizzarello R, Klein I. Enhanced left ventricular diastolic function in hyperthyroidism: noninvasive assessment and response to treatment. J Clin Endocrinol Metab 73, 146-150, 1991.

Montero-Pedrazuela A, Venero C, Lavado-Autric R, Fernandez-Lamo I, Garcia-Verdugo JM, Bernal J, Guadano-Ferraz A. Modulation of adult hippocampal neurogenesis by thyroid hormones: implications in depressive-like behavior. Mol Psychiatry 11, 361-371, 2006.

Morkin E, Edwards JG, Tsika RW, Bahl JJ, Flink IL. Regulation of human cardiac myosin heavy chain gene expression by thyroid hormone. Adv Exp Med Biol 308, 143-147, 1991.

Morkin E. Regulation of myosin heavy chain genes in the heart. Circulation 87, 1451-1460, 1993.

Morte B, Manzano J, Scanlan T, Vennstrom B, Bernal J. Deletion of the thyroid hormone receptor alpha 1 prevents the structural alterations of the cerebellum induced by hypothyroidism. Proc Natl Acad Sci USA 99, 39853989, 2002.

Naidoo S, Valcana T, Timiras PS. Thyroid hormone receptors in the developing rat brain. Amer Zool 18, 545-552, 1978.

Nelson CC, Hendy SC, Faris JS, Romaniuk PJ. The effects of P-box substitutions in thyroid hormone receptor on DNA binding specificity. Mol Endocrinol 8, 829-840, 1994.

Nevado J, Tenbaum SP, Aranda A. hSrb7, an essential human mediator component, acts as a coactivator for the thyroid hormone receptor. Mol. Cell. Endocrinol 222, 41-51, 2004.

Niazi AK, Kalra S, Irfan A, Aliya Islam A. Thyroidology over the ages. Indian J Endocrinol Metab 15 (Suppl 2), S121S126, 2011.

Norman MF, Lavin TN, Baxter JD, West BL. The rat growth hormone gene contains multiple thyroid response elements. J Biol Chem 264, 12063-12073, 1989.

Oppenheimer JH, Koerner D, Schwartz HL, Surks MI. Specific nuclear triiodothyronine binding sites in rat liver and kidney. J Clin Endocrinol Metab 35, 330-333, 1972.

Oppenheimer JH, Schwartz HL, Surks MI. Tissue differences in the concentration of triiodothyronine nuclear binding sites in the rat: Liver, kidney, pituitary, heart, brain, spleen and testes. Endocrinology 95, 897-903, 1974.

Oppenheimer JH, Schwartz HL, Surks MI, Koerner D, Dillmann WH. Nuclear receptors and the initiation of thyroid hormone action. Recent Prog Horm Res 32, 529-565, 1976.

Oppenheimer JH. Evolving concepts of thyroid hormone action. Biochimie 81, 539-543, 1999.

Ortega FJ, Vazquez-Martin A, Moreno-Navarrete JM, Bassols J, Rodriguez-Hermosa J, Girones J, Ricart W, Peral B, Tinahones FJ, Fruhbeck G, Menendez JA, Fernandez-Real JM. Thyroid hormone responsive Spot 14 increases during differentiation of human adipocytes and its expression is down-regulated in obese subjects. Int J Obes (Lond) 34, 487-499, 2010.

Pascual A, Aranda A. Thyroid hormone receptors, cell growth and differentiation. Biochim Biophys Acta 1830, 39083916, 2013.

Petty KJ, Morioka H, Mitsuhashi T, Nikodem VM. Thyroid hormone regulation of transcription factors involved in malic enzyme gene expression. J Biol Chem 264, 11483-11490, 1989. 
Plateroti M, Chassande O, Fraichard A, Gauthier K, Freund JN, Samarut J, Kedinger M. Involvement of T3Ralphaand beta-receptor subtypes in mediation of T3 functions during postnatal murine intestinal development. Gastroenterology 116, 1367-1378, 1999.

Plateroti M, Gauthier K, Domon-Dell C, Freund JN, Samarut J, Chassande O. Functional interference between thyroid hormone receptor alpha (TRalpha) and natural truncated TRDeltaalpha isoforms in the control of intestine development. Mol Cell Biol 21, 4761-4772, 2001.

Poddar R, Paul S, Chaudhury S, Sarkar PK. Regulation of actin and tubulin gene expression by thyroid hormone during rat brain development. Brain Res Mol Brain Res 35, 111-118, 1996.

Puca GA, Abbondanza C, Nigro V, Armetta I, Medici N, Molinari AM. Estradiol receptor has proteolytic activity that is responsible for its own transformation. Proc Natl Acad Sci USA 83, 5367-5371, 1986.

Puzianowska-Kuznicka M, Krystyniak A, Madej A, Cheng SY, Nauman J. Functionally impaired TR mutants are present in thyroid papillary cancer. J Clin Endocrinol Metab 87, 1120-1128, 2002.

Refetoff S, DeWind LT, DeGroot LJ. Familial syndrome combining deaf-mutism, stuppled epiphyses, goiter and abnormally high PBI: possible target organ refractoriness to thyroid hormone. J Clin Endocrinol Metab 27, 279-294, 1967.

Refetoff S, Dumitrescu AM. Syndromes of reduced sensitivity to thyroid hormone: genetic defects in hormone receptors, cell transporters and deiodination. Best Pract Res Clin Endocrinol Metab 21, 277-305, 2007.

Refetoff S, Bassett JH, Beck-Peccoz P, Bernal J, Brent G, Chatterjee K, De Groot LJ, Dumitrescu AM, Jameson JL, Kopp PA, Murata Y, Persani L, Samarut J, Weiss RE, Williams GR, Yen PM. Classification and proposed nomenclature for inherited defects of thyroid hormone action, cell transport, and metabolism. J Clin Endocrinol Metab 99, 768-770, 2014.

Ritter MJ, Amano I, Hollenberg AN. Thyroid hormone signaling and the liver. Hepatology 72, 742-752, 2020.

Rosenfeld MG, Lunyak VV, Glass CK. Sensors and signals: A coactivator/corepressor/epigenetic code for integrating signal-dependent programs of transcriptional response. Genes Dev 20, 1405-1428, 2006.

Ruiz-Llorente L, Ardila-Gonzalez S, Fanjul LF, Martinez-Iglesias O, Aranda A. microRNAs 424 and 503 are mediators of the anti-proliferative and anti-invasive action of the thyroid hormone receptor beta. Oncotarget 5, 2918-2933, 2014.

Samuels HH, Tsai JS. Thyroid hormone action in cell culture: demonstration of nuclear receptors in intact cells and isolated nuclei. Proc Natl Acad Sci USA 70, 3488-3492, 1973.

Samuels HH, Tsai JS, Casanova J. Thyroid hormone action: In vitro demonstration of putative receptors in isolated nuclei and soluble nuclear extracts. Science 184, 1188-1191, 1974.

Samuels HH, Stanley F, Casanova J. Relationship of receptor affinity to the modulation of thyroid hormone nuclear receptor levels and growth hormone synthesis by L-triiodothyronine and iodothyronine analogues in cultured GH1 cells. J Clin Invest 63, 1229-1240, 1979.

Sanchez-Martinez R, Castillo AI, Steinmeyer A, Aranda A. The retinoid X receptor ligand restores defective signalling by the vitamin D receptor, EMBO Rep 7, 1030-1034, 2006.

Sap J, Munoz A, Damm K, Goldberg Y, Ghysdael J, Leutz A, Beug H, Vennstrom B. The c-erb-A protein is a highaffinity receptor for thyroid hormone. Nature 324, 635-640, 1986.

Schmutzler C, Brtko J, Winzer R, Jakobs TC, Meissner-Weigl J, Simon D, Goretzki PE, Kohrle J. Functional retinoid and thyroid hormone receptors in human thyroid-carcinoma cell lines and tissues. Int J Cancer 76, 368-376, 1998.

Shibata H, Spencer TE, Onate SA, Jenster G, Tsai SY, Tsai MJ, O’Malley BW. Role of co-activators and co-repressors in the mechanism of steroid/thyroid receptor action. Recent Prog Horm Res 52, 141-164, 1997.

Silva JF, Ocarino NM, Serakides R. Thyroid hormones and female reproduction. Biol Reprod 99, 907-921, 2018.

Simonet WS, Ness GC. Transcriptional and posttranscriptional regulation of rat hepatic 3-hydroxy-3-methylglutaryl-coenzyme A reductase by thyroid hormones. J Biol Chem 263, 12448-12453,1988.

Smith CL, O'Malley BW. Coregulator function: A key to understanding tissue specificity of selective receptor modulators. Endocr Rev 25, 45-71, 2004.

Spaulding SW, Davis PJ. Thyroxine binding to soluble proteins in rat liver and its sex dependence. Biochim Biophys Acta 229, 279-283, 1971.

Sterling K, Milch PO, Brenner MA, Lazarus JH. Thyroid hormone action: the mitochondrial pathway. Science 197, 996-999, 1977.

Sugie H, Verity MA. Postnatal histochemical fiber type differentiation in normal and hypothyroid rat soleus muscle. Muscle Nerve 8, 654-660,1985.

Sun H, Cao L, Zheng R, Xie S, Liu C. Update on resistance to thyroid hormone syndrome $\beta$. Ital J Pediatr 46, $168,2020$. 
Surks MI, Koerner D, Dillmann W, Oppenheimer JH. Limited capacity binding sites for L-triiodothyronine (T3) in rat liver nuclei: Localization to the chromatin and partial characterization of the T3-chromatin complex, J Biol Chem 248, 7066-7072, 1973.

Surks MI, Koerner DH, Oppenheimer JH. In vitro binding of L-triiodothyronine to receptors in rat liver nuclei: Kinetics of binding, extraction properties, and lack of requirement for cytosol proteins J Clin Invest 55, 50-60, 1975.

Tabachnick II, Bonnycastle DD, Salter WT. The distribution of ${ }^{131} \mathrm{I}$ - and ${ }^{131} \mathrm{I}$-labelled thyroxine in rat liver homogenates. J Endocrinol 10, 302-304, 1954.

Tang Y, Yu M, Lian X. Resistance to thyroid hormone a, revelation of basic study to clinical consequences. J Pediatr Endocrinol Metab 29, 511-522, 2016.

Tata JR, Ernster L, Suranyi EM. Interaction between thyroid hormones and cellular constituents. I. Binding to isolated sub-cellular particles and sub-particulate fractions. Biochim Biophys Acta 60, 461-479, 1962.

Tata JR, Ernster L, Lindberg O, Arrhenius E, Pederson S, Hedman R. The action of thyroid hormones at the cell level. Biochem J 86, 408-428, 1967.

Thompson CC, Weinberger C, Lebo R, Evans RM. Identification of a novel thyroid hormone receptor expressed in the mammalian central nervous system. Science 237, 1610-1614, 1987.

Torresani J, DeGroot LJ. Triiodothyronine binding to liver nuclear solubilized proteins in vitro. Endocrinology 96 , 1201-1209, 1975.

Tribulova N, Kurahara LH, Hlivak P, Hirano K, Szeiffova Bacova B. Pro-arrhythmic signaling of thyroid hormones and its relevance in subclinical hyperthyroidism. Int J Mol Sci 21, 2844, 2020.

Umesono K, Evans RM. Determinants of target gene specificity for steroid/thyroid hormone receptors. Cell 57, 11391146, 1989.

Usala SJ, Bale AE, Gesundheit N, Weinberger C, Lash RW, Wondisford FE, McBride OW, Weintraub BD. Tight linkage between the syndrome of generalized thyroid hormone resistance and the human c-erbA beta gene. Mol Endocrinol 12, 1217-1220, 1988a.

Usala SJ, Young WS $3^{\text {rd }}$, Morioka H, Nikodem VM. The effect of thyroid hormone on the chromatin structure and expression of the malic enzyme gene in hepatocytes. Mol Endocrinol 2, 619-626, 1988b.

Vallejo CG, Seguido AM, Testillano PS, Risueno MC. Thyroid hormone regulates tubulin expression in mammalian liver. Effects of deleting thyroid hormone receptor-alpha or -beta. Am J Physiol Endocrinol Metab 289, E87E94, 2005

Verga Falzacappa C, Panacchia L, Bucci B, Stigliano A, Cavallo MG, Brunetti E, Toscano V, Misiti S. 3,5,3区-Triiodothyronine (T3) is a survival factor for pancreatic beta-cells undergoing apoptosis. J Cell Physiol 206, 309-321, 2006.

Viguerie N, Langin D. Effect of thyroid hormone on gene expression. Curr Opin Clin Nutr Metab Care 6, 377-381, 2003.

Visser WE. Therapeutic applications of thyroid hormone analogues. Ann Endocrinol (Paris) 4, S0003-4266(20)30039_ 1, 2020. Epub ahead of print.

Wahlstrom GM, Sjoberg M, Andersson M, Nordstrom K, Vennstrom B. Binding characteristics of the thyroid hormone receptor homo- and heterodimers to consensus AGGTCA repeat motifs. Mol Endocrinol 6, 1013$1022,1992$.

Waung JA, Bassett JH, Williams GR. Thyroid hormone metabolism in skeletal development and adult bone maintenance. Trends Endocrinol Metab 23, 155-162, 2012.

Weinberger C, Thompson CC, Ong ES, Lebo R, Gruol DJ, Evans RM. The c-erb-A gene encodes a thyroid hormone receptor. Nature 324, 641-646, 1986

Weiss RE, Xu J, Ning G, Pohlenz J, O'Malley BW, Refetoff S. Mice deficient in the steroid receptor co-activator 1 (SRC1) are resistant to thyroid hormone. Embo J 18, 1900-1904. 1999.

Williams GR. Cloning and characterization of two novel thyroid hormone receptor beta isoforms. Mol Cell Biol 20, 8329-8342, 2000.

Yamada S, Kakuta H. Retinoid X receptor ligands: A patent review (2007 - 2013). Expert Opin Ther Pat 24, 443-452, 2014.

Ye ZS, Forman BM, Aranda A, Pascual A, Park HY, Casanova J, Samuels HH. Rat growth hormone gene expression. Both cell-specific and thyroid hormone response elements are required for thyroid hormone regulation. J Biol Chem 263, 7821-7829, 1988.

Yen PM. Physiological and molecular basis of thyroid hormone action. Physiol Rev 81, 1097-1142, 2001.

Yen PM. Molecular basis of resistance to thyroid hormone. Trends Endocrinol Metab 14, 327-333. 2003. 
Yen PM, Feng X, Flamant F, Chen Y, Walker RL, Weiss RE, Chassande O, Samarut J, Refetoff S, and Meltzer PS. Effects of ligand and thyroid hormone receptor isoforms on hepatic gene expression profiles of thyroid hormone receptor knockout mice. EMBO Rep 4, 581-587, 2003.

Yin L, Wang Y, Dridi S, Vinson C, Hillgartner FB. Role of CCAAT/enhancer-binding protein, histone acetylation, and coactivator recruitment in the regulation of malic enzyme transcription by thyroid hormone. Mol Cell Endocrinol 245, 43-52, 2005.

Xiao L, Xie X, Zhai Y Functional crosstalk of CAR-LXR and ROR-LXR in drug metabolism and lipid metabolism. Adv Drug Deliv Rev 62, 1316-1321, 2010.

Zambrano A, Garcia-Carpizo V, Gallardo ME, Villamuera R, Gomez-Ferreria MA, Pascual A, Buisine N, Sachs LM, Garesse R, Aranda A. The thyroid hormone receptor $\beta$ induces DNA damage and premature senescence. J Cell Biol 204, 129-146, 2014.

Zechel C, Shen XQ, Chen JY, Chen ZP, Chambon P, Gronemeyer H. The dimerization interfaces formed between the DNA binding domains of RXR, RAR and TR determine the binding specificity and polarity of the fulllength receptors to direct repeats. EMBO J 13, 1425-1433, 1994.

Zhu XG, Zhao L, Willingham MC, Cheng SY. Thyroid hormone receptors are tumor suppressors in a mouse model of metastatic follicular thyroid carcinoma. Oncogene 29, 1909-1919, 2010. 